\title{
HUBUNGAN PERSEPSI DAN PENGETAHUAN PRIA USIA SUBUR MENGENAI METODE KONTRASEPSI MANTAP DI WILAYAH KERJA PUSKESMAS REJOSARI PEKANBARU 2016
}

\author{
Emi Yulita \\ Kebidanan, STIKes Tengku Maharatu Pekanbaru, yulita emi@yahoo.com
}

\begin{tabular}{l} 
INFO ARTIKEL \\
RiwayatArtikel: \\
Diterima: 8-01-2018 \\
Disetujui: $31-01-2018$ \\
\hline
\end{tabular}

\section{Kata Kunci:}

Persepsi,

Pengetahuan

Pria Usia Subur,

Metode Kontrasepsi Mantap

\begin{abstract}
ABSTRAK
Abstrak: Partisipasi pria menjadi penting dalam Keluarga Berencana (KB) dan Kesehatan Reproduksi karena pria adalah partner dalam kesehatan reproduksi dan seksual. Penelitian ini mengunakan jenis penelitian kuantitatif, lokasi penelitian di wilayah kerja Puskesmas Rejosari. Populasi dalam penelitian ini adalah Pria usia subur sebanyak 63 responden, pengambilan sampel mengunakan teknik random sampling dan dianalisis data mengunakan uji statistik Chi-square. Hasil Penelitian diperoleh nilai $X^{2}$ hitung $>X^{2}$ tabel $(23,532>5,991)$ artinya ho ditolak adanya hubungan antara keduanya. Disarankan kepada Pria Usia Subur, tidak mempercayai adanya rumor tentang Vasektomi, pembinaan pasca pelayanan, di bentuk paguyuban "Prio Utomo".

Abstract: Male participation is important in Family Planning and Reproductive Health because men are partners in reproductive and sexual health. This research uses quantitative research type, research location in work area of Rejosari Public Health Center. The population in this study were fertile aged men as much as 63 respondents, sampling using random sampling technique and analyzed data using Chi-square statistical test. The result of research is X2count> X2tabel $(23,532>5,991)$ meaning ho rejected the relationship between the two. Suggested to Man Age Fertile, do not believe the existence of rumors about Vasectomy, coaching post service, in form paguyuban "Prio Utomo".
\end{abstract}




\section{A. LATAR BELAKANG}

Keluarga Berencana (KB) adalah program nasional yang bertujuan meningkatkan derajat kesehatan, secara umum meningkatkan kesejahteraan bangsa dan khususnya kesejahteraan ibu, anak dan keluarga. (Badan Pusat Statistik, 2014).

Penurunan jumlah penduduk Indonesia dapat dilihat dari jumlah angka kelahiran. Jumlah angka kelahiran di Indonesia pada sensus tahun 2010 adalah 28 per 1.000 jumlah penduduk, pada tahun 2012 menurun menjadi 23 per 1.00o, jumlah penduduk dan tahun 2014 menurun menjadi 22 angka kelahiran per 1.000 jumlah penduduk (Survey Demografi Kesehatan Indonesia, 2014).

Penurunan angka kelahiran tidak terlepas dari keberhasilan program $\mathrm{KB}$ di Indonesia. Keberhasilan program $\mathrm{KB}$ juga dapat dilihat dari jumlah cakupan akseptor KB yang terus meningkat, pada tahun 2002 terdapat 21.109 akseptor KB, tahun 2005 meningkat menjadi 26.186 akseptor KB tahun 2008 meningkat kembali menjadi 26.886, akseptor KB dan tahun 2011 terjadi peningkatan menjadi 27.857. Walaupun program KB sudah terbilang berhasil, namun program $\mathrm{KB}$ tersebut harus terus ditingkatkan dan diperhatikan, karena pencapaian program KB belum merata (Saputra, 2012).

Jumlah cakupan KB yang belum merata dapat dilihat dari perbedaan jumlah cakupan alat kontasepsi yang dipergunakan akseptor. Pengguna alat kontrasepsi adalah wanita dan pria. Pada wanita, ada beberapa pilihan alat kontaselpsi antara lain: Pil, Alat Kontrasepsi Dalam Rahim (AKDR), Suntik, Kontrasepsi Mantap (Kontap) seperti tubektomi. Pada pria, pilihan alat kontrasepsi yang dapat digunakan adalah Kondom dan Kontrasepsi Mantap (Kontap) atau disebut Metode Operasi Pria (MOP) yaitu Vasektomi. Alat kontrasepsi yang sering digunakan oleh pria adalah kondom (Hartanto, 2004).

Kondom merupakan alat kontrasepsi yang dapat mencegah kehamilan, memberi perlindungan terhadap penyakit akibat hubungan seksual, sederhana, ringan tidak memerlukan pemeriksaan medis dan bersifat reversibel. Kondom juga memiliki kerugian diantaranya angka kegagalan relatif tinggi, harus dipakai secara benar dan konsisten setiap senggama, karena umumnya kegagalan yang timbul disebabkan pemakaian yang tidak benar, tidak konsisten, tidak teratur dan tidak berhati-hati. (Hartanto, 2004).

Pada kenyataannya lebih dominan wanita yang menggunakan alat kontasepsi. Banyak faktor yang mempengaruhi penggunaaan alat kontrasepsi tersebut. Salah satu faktor adalah perbedaan pandangan gender yaitu pembagian peran yang tidak sama antara laki-laki dan perempuan. Perempuan dianggap lebih dominan yang bertanggung jawab. Hal ini tidak terlepas dari budaya masyarakat yang memandang wanita sebagai pihak yang berada dibawah, ideologi patriakis, posisi wanita yang lemah, negosiasi penggunaan kontap yang lemah oleh wanita, keputusan yang selalu ada ditangan pria, ketidakpedulian pria terhadap kesehatan reproduksi dan pria merasa tidak nyaman berdiskusi tentang $\mathrm{KB}$ dengan pasangannya saja ( Riyadi, 2007).

Di Provinsi Riau, pada tahun 2012 jumlah PUS adalah 107.512. dari jumlah tersebut yang aktif menggunakan alat kontrasepsi sebanyak 89.880 (83,59\%). Jumlah wanita aseptor KB sebanyak 85.175 orang $(94,76 \%)$ sangat jauh berbeda bila dibandingkan dengan pria aseptor KB yaitu sebanyak 4.705 orang $(5,23 \%)$. Dari alat kontrasepsi yang digunakan pria, kondom adalah pilihan yang dominan yaitu sebanyak 4.612 orang (98,02\%), sedangkan yang melakukan vasektomi hanya 86 orang $(1,82 \%)$ (BKKBN, 2011). Tahun 2015 adalah 131.310 yang aktif sebagai akseptor KB sebanyak $89.877(68,4 \%)$. Jumlah wanita akseptor KB sebanyak 85.175 orang (94,5\%), sedangkan pria akseptor KB sebanyak 4.705 orang $(5,2 \%)$, dari jumlah tersebut ,pria yang menggunakan kondom $(5,1 \%)$ dan kontap hanya (0,09\%)

Pemerintah telah menyusun kebijakan untuk meningkatkan partisipasi pria sebagai akseptor $\mathrm{KB}$ dengan cara menanggung biaya pelayanan kesehatan masyarakat miskin untuk melakukan program KB kontap.

Rendahnya partisipasi pria menurut Worth Health Organization WHO dipengaruhi oleh: 1) Pemikiran dan perasaan dalam bentuk pengetahuan, Persepsi, Sikap, kepercayaan dan penilaian terhadap objek; 2) Orang penting sebagai referensi; 3) Sumber daya yang ada dimasyarakat; 4) Kebudayaan yang ada dimasyarakat (Notoadmodjo, 2003).

\section{B. METODE PENELITIAN}

Jenis penelitian adalah kuantitatif yaitu suatu proses penelitian mulai dari merumuskan permasalahan hingga mengambil kesimpulan. Sedangkan rancangan penelitian ini bersifat deskriptif analitik yaitu jenis penelitian yang bertujuan mencari hubungan antar variabel independen dan dependen

Populasi adalah keseluruhan objek penelitian Populasi dalam penelitian ini semua Pria Usia Subur (PUS) yang berada di RW 1 RT 2 Kelurahan Rejosari Wilayah Kerja Puskesmas Rejosari Pekanbaru yang berjumlah 75 orang.

Sampel sebanyak 63 orang dengan Teknik pengambilan sampel yang digunakan adalah dengan metode Random Sampling adalah dengan mengambil responden secara acak, hal ini berarti setiap anggota populasi mempunyai kesempatan 
yang sama untuk diambil sebagai sampel. Dengan teknik random sampel yang digunakan adalah pengambilan sampel secara acak sederhana (simple random sampling) yaitu dengan mengundi anggota populasi (lottrey technique) atau teknik undian

Analisa bivariate mencari hubungan antara pengetahuan dengan dengan rendahnya minat pria menggunakan kontap. Dasar pengambilan keputusan yaitu dengan membandingkan nilai $\mathrm{x}^{2}$ hitung dengan nilai $\mathrm{x}^{2}$ tabel, sebagai berikut : Jika $\mathrm{x}^{2}$ hitung $\geq \mathrm{x}^{2}$ tabel, maka Ho ditolak artinya signifikan. Jika $\mathrm{x}^{2}$ hitung $<\mathrm{x}^{2}$ tabel, maka Ho diterima artinya tidak signifikan.

\section{HASIL DAN PEMBAHASAN}

\section{Analisis Univariat}

TABEL 1

Distribusi Frekuensi Responden Berdasarkan Tingkat Pengetahuan Pria di Wilayah

Kerja Puskesmas Rejosari

\begin{tabular}{|c|l|c|c|}
\hline No & Kategori & Frekuensi (n) & Persentase (\%) \\
\hline 1 & Kurang & 29 & 46,0 \\
2 & Cukup & 23 & 36,5 \\
3 & Baik & 11 & 17,5 \\
\hline \multicolumn{2}{|c|}{ Total } & $\mathbf{6 3}$ & $\mathbf{1 0 0}$ \\
\hline
\end{tabular}

Berdasarkan Tabel 1 maka dapat disimpulkan bahwa dari 63 orang Pria minoritas 11 orang (17,5\%) Pengetahuan Baik dan mayoritas 29 orang (46,0\%) dengan Pengetahuan kurang.

\section{TABEL 2}

Distribusi Frekuensi Responden Berdasarkan Persepsi Pria di Wilayah Kerja Puskesmas Rejosari

\begin{tabular}{|c|l|c|c|}
\hline No & Kategori & Frekuensi (n) & Persentase (\%) \\
\hline 1 & Negatif & 28 & 44,4 \\
2 & Postif & 35 & 55,6 \\
\hline \multicolumn{2}{r|}{ Total } & $\mathbf{6 3}$ & $\mathbf{1 0 0}$ \\
\hline
\end{tabular}

Berdasarkan Tabel 2 maka dapat disimpulkan bahwa dari 63 orang Pria mayoritas 35 orang (55,6\%) dengan Persepsi positif.

\section{Analisis Bivariat}

\section{TABEL 3}

Hubungan Antara Persepsi dan Pengetahuan Pria Usia Subur Mengenai Metode Kontrasepsi Mantap di Wilayah Kerja Puskesmas Rejosari Pekanbaru

$$
2016
$$

\begin{tabular}{|l|c|c|c|c|c|}
\hline \multirow{2}{*}{$\begin{array}{l}\text { Persep } \\
\text { si }\end{array}$} & \multicolumn{3}{|c|}{ Pengetahuan Pasien } & Jumlah & $\begin{array}{c}\boldsymbol{X}^{\mathbf{2}} \\
\text { Hitung }\end{array}$ \\
\cline { 2 - 5 } & Kurang & Cukup & Baik & $\mathrm{F}$ & \\
\hline Negatif & $\begin{array}{c}22 \\
(34,9 \%)\end{array}$ & $\begin{array}{c}6 \\
(9,5 \%)\end{array}$ & $\begin{array}{c}\mathrm{O} \\
(0 \%)\end{array}$ & $\begin{array}{c}28 \\
(44,4 \%)\end{array}$ & \multirow{2}{*}{23,532} \\
\hline Positif & $\begin{array}{c}7 \\
(11,1 \%)\end{array}$ & $\begin{array}{c}17 \\
(27 \%)\end{array}$ & $\begin{array}{c}11 \\
(17,5 \%)\end{array}$ & $\begin{array}{c}35 \\
(55,6 \%)\end{array}$ & \\
\cline { 1 - 5 } Jumlah & $\begin{array}{c}29 \\
(46,0 \%)\end{array}$ & $\begin{array}{c}23 \\
(36,5 \%)\end{array}$ & $\begin{array}{c}11 \\
(17,5 \%)\end{array}$ & $\begin{array}{c}63 \\
(100 \%)\end{array}$ & \\
\hline
\end{tabular}

Berdasarkan tabel 3 menunjukkan bahwa dari 63 orang responden di dapatkan sebagian besar 34,9 \% pengetahuan kurang, tetapi persepsi responden menunjukkan kurang 44,4 \%. Hasil uji statistik diperoleh nilai $\mathrm{Chi}-$ Square hitung sebesar 23,532. Adapun besar Chi - Square tabel dengan $\mathrm{df}=2$ pada taraf signifikasi sebesar $95 \%(0,05)$ didapatkan nilai sebesar 5,991. Hasil tersebut menunjukkan nilai Chi - Square hitung lebih besar dari ChiSquare tabel $(23,532>5,991)$, maka dapat disimpulkan bahwa terdapatnya Hubungan Persepsi dan Pengetahuan Pria Usia Subur Mengenai Metode Kontrasepsi Mantap (Vasektomi) Di Wilayah Kerja Puskesmas Tenayan Raya Pekanbaru 2016

Dari analisa yang dilakukan dalam penelitian ini maka telah didapatkan distribusi frekuensi Persepsi Pria pada metode kontrasepsi Mantap (Vasektomi) minoritas 28 orang $(44,4 \%)$ dengan Pengetahuan Kurang 22 orang, Cukup 6 orang, Selanjutnya Persepsi Postif 35 orang $(55,6 \%)$ dengan pengetahuan kurang 7 orang, cukup 17 orang dan baik 11 orang, Selanjutnya dapat dibandingkan $X^{2}$ hitung dengan $X^{2}$ tabel dengan hasil ternyata $X^{2}$ hitung $>X^{2}$ tabel atau ( $23,532>5,991$, ) maka Ho ditolak artinya ada hubungan yang signifikan antara Hubungan Persepsi dan Pengetahuan Pria Usia Subur Mengenai Metode Kontrasepsi Mantap (Vasektomi) di Wilayah Kerja Puskesmas Rejosari Pekanbaru 2016.

Hasil Analisa ini didukung oleh beberapa teori dan pendapat diantaranya, Pria atau suami, memiliki peran lebih dominan dalam mengambil keputusan terhadap kesehatan reproduksi wanita. Namun, informasi yang benar tentang kesehatan reproduksi bagi pria di Indonesia masih sangat kurang. Terutama, mereka tidak punya banyak pilihan dalam menggunakan metode kontrasepsi yang cocok, Memasuki awal perkawinan, suami memiliki peran penting dalam menentukan kelahiran anak. Dari perencanan keluarga yang meliputi penentuan jumlah anak, kapan istri hamil, dimana istri akan melahirkan, ditolong oleh siapa dan sebagainya, merupakan peran suami dalam menjaga kesehatan reproduksi. Ketika istri hamil, suami bisa menjamin bahwa istri melakukan pemeriksaan yang baik dan teratur, memperoleh makanan bergizi, bahwa istri merasa tenang dan bahagia.

Hasil ini sangat perlu sekali untuk dinilai karena pengetahuan pada dasarnya merupakan hal yang sangat pribadi, sifatnya kontekstual dan berasal dari pengalaman pribadi, penafsiran makna, relevansi yang dirasakan oleh individu (Nelms 1991) Pengetahuan merupakan respon internal dari perilaku yang terselubung/covert Behavior Perlu dilakukan pengkajian secara lisan atau tulisan untuk mengetahui tingkat pengetahuan seseorang. Hasil analisa data pada distribusi frekuensi padapersepsi dan pengetahuan ini kurang, hal ini didukung oleh pernyataan bahawa tingkat 
pengetahuan seseorang dipengaruhi oleh beberapa faktor yakni dengan latar belakang pendidikan , sosial budaya dan pekerjaan.

Hasil penelitian ini sangat sesuai dengan pendapat Notoadmodjo Salah satu faktor yang mempengaruhi tingkat pengetahuan adalah tingkat pendidikan, dan mengemukakan bahwa semakin tinggi tingkat pendidikan seseorang semakin tinggi pula tingkat pengetahuannya dan semakin mudah seseorang untuk memahami pengetahuan, dan begitu pula sebaliknya semakin rendah tingkat pendidikan seseorang maka semakin rendah pula tingkat pengetahuannya.Menurut (Ngastyah 2003) Pengetahuan yang kurang bisa mengakibatkan oleh berbagai faktor - faktor diantaranya Lingkungan, makanan, dan pengalaman seorang pria yang tidak mendukung. Sementara Menurut Sarwono (1997) pengetahuan dapat di pengaruhi oleh Pendidikan, pekerjaan sehingga pengetahuan bisa juga dipengaruhi oleh karakteristik yang meliputi jenis kelamin, umur dan adat istiadat.

\section{SIMPULAN DAN SARAN}

Berdasarkan analisa data pada hubungan antara keduanya dengan diperoleh nilai $\mathrm{X}^{2}$ hitung $>\mathrm{X}^{2}$ tabel $(23,532>5,991$,) maka Ho ditolak artinya ada hubungan yang signifikan antara Hubungan Persepsi dan Pengetahuan Pria Usia Subur Mengenai Metode Kontrasepsi Mantap

Disarankan sebaiknya responden dapat lebih mendalami dan mencari informasi lebih banyak lagi terutama Metode Kontrasepsi Mantap, sehingga pria bisa menyadari bahwa ber $\mathrm{KB}$ itu bukan saja pada ibu - ibu tapi perlu juga bagi pria.

\section{UCAPAN TERIMA KASIH}

1. Ibu Ns. Erika, M.Kep, Sp. Mat selaku Ketua Yayasan Tengku Maharatu Pekanbaru, yang telah memberikan kesempatan kepada saya untuk melakukan penelitian

2. Ibu Sri Wardani, M.Kes, selaku Ketua STIKes Tengku Maharatu Pekanbaru, yang telah banyak memberikan masukan dan saran kepada saya dalam melakukan peneliti ini

3. Ibu Lia Fentia, SST. M.Kes selaku Ketua LPPM yang telah memfasilitasi saya dalam melakukan penelitian ini

4. Bapak/Ibu Pimpinan Puskesmas Rejosari Pekanbaru yang telah memberikan izin kepada saya untuk melakukan peneliti ini

\section{DAFTAR RUJUKAN}

Anna, G, Keluarga Berencana dan Kesehatan Reproduksi., EGC, Jakarta, 2005.

Hartanto, H, Keluarga Berencana dan Kontrasepsi, Pustaka Sinar Harapan, Jakarta, 2004.

Hidayat, A, A, Riset Keperawatan dan Tehnik Penulisan Ilmiah, Penerbit Salemba Medika, Jakarta, 2008.
Purwanti, NS, Hubungan Antara Persepsi Suami Tentang Alat Kontrasepsi Pria Dengan Penggunaan Alat Kontrasepsi Pria di Kabupaten Bantu. Tesis Program Studi Ilmu Kesehatan Masyarakat Jurusan Kesehatan Ibu dan Anak, 2004

Sastroasmoro, S, Dasar-dasar Metodologi Penelitian Klinis, Sagung Seto, Jakarta, 2002.

SDKI, Survei Demografi Kesehatan Indonesia Statistic Indonesia, Jakarta .2003

Sitompul, H, Program Menjamin Mutu Pelayanan

Kontrasepsi Mantap. Cermin Dunia Kedokteran. ,Ed Khusus. No. 8o, 1998.

Sugiyono, Statistika Untuk penelitian, IKAPI, Bandung, 2003

Suzanna, E, Buku Saku Kontrasepsi dan Kesehatan Seksual Reproduksitif, Buku

Kedokteran EGC, Jakarta, 2007

\section{PROFIL PENULIS UTAMA}

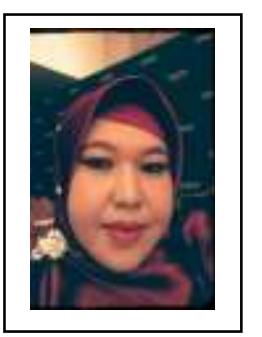

Emi Yulita: Lahir di Sumatera Barat dengan riwayat pendidikan th 1990 menyelesaikan MTsN di Payakumbuh, th 1996 melanjutkan SPK di Padang, th 2000 menyelesaikan Diploma III Kebidanan di Padang, th 2005 menyelesaikan pendidikan DIV Bidan Pendidik di Universitas Gajah Madha Yogyakarta dan tahun 2016 menyelesaikan pendidikan S2 Kebidanan di Universitas Hasanuddin Makassar. Penelitian yang telah dipublikasi: Hubungan Umur dan Paritas Ibu terhadap kejadian Preeklamsia pada ibu Bersalin di RSUD Arifin Achmad Pekanbaru, dipublikasikan pada jurnal Menara ilmu Universitas Muhammadiyah Sumatera Barat vol.X jilid 2 No.63 Januari 2016 ISSN 16932617. Hubungan Pengetahuan ibu hamil tentang Gizi Terhadap Status Gizi ibu Hamil di Wilayah kerja Puskesmas Rejosari Pekanbaru, dipublikasikan pada Jurnal JKTM (Jurnal Kesehatan Tengku Maharatu) Vol.3, No.3, Agustus 2016 dengan p-ISSN: 2460-6596, e-ISSN: 2597 - 906X. Pengabdian Masyarakat yang telah dilakukan: Penyuluhan pada masyarakat tentang mengetahui karakteristik ibu hamil yang mengalami Preeklamsia, Penyuluhan tentang Sadari di SMK Hasanah Pekanbaru dan Penyuluhan Senam hamil pada ibu hamil di Puskesmas Siak Hulu I Pekanbaru.

\section{Korespondensi:}

Emi Yulita

STIKes Tengku Maharatu Pekanbaru

HP No. 085364156848

email: yulitaemi@yahoo.com 